\title{
KNOWLEDGE, EXPERIENCE, FINANCIAL SATISFACTION, AND INVESTMENT DECISIONS: GENDER AS A MODERATING VARIABLE
}

\author{
Tri Kartika Pertiwi ${ }^{*}$, Nuruni Ika Kusuma Wardani ${ }^{2}$, Icasania Septentia ${ }^{3}$ \\ 1,2,3 UPN "Veteran” Jawa Timur, Raya Rungkut Madya, Surabaya 60294, Indonesia. \\ *Corresponding author; email: tri.pertiwi.mnj@upnjatim.ac.id
}

\begin{abstract}
This research aimed to analyze and examine the effect of financial experience, financial knnowledge, and financial satisfaction to the decision making of investor's investment with gender as a moderation variable. The method of analysis employed was Partial Least Square (PLS). Meanwhile, the research result showed that the knowledge variable, experience, and financial satisfaction significantly affected to the decision making of investment. However, gender as a moderation variable was not significantly strengthening to that relationship. Finally, it could be concluded that in decision making we had to consider several factors like knowledge, experience, and satisfaction in efforts to increase the investor's prosperity or well-being.
\end{abstract}

Keywords: Investment; experience; knnowledge; satisfaction; gender.

\section{Introduction}

In general, if we want to get provit in the future, we may invest our money by investing our extra fund or money. Investment might be in some kinds of real asset or non real such as marketable securities. The research dealing with money market in Indonesia was conducted by (Pertiwi, Yuniningsih, \& Anwar, 2019). It was said that an investor having a strong self-confidence, he had too many kinds of different activities to do trading. Therefore, to get an exact decision in investment, the financial literacy or a knowledge in terms of finance is becoming the basic principle in the financial decision making. Based on several other researches conducted in many other countries dealing with financial knowledge showed that most of the investors had a low level of this financial knowledge either the old generation, women and those having low education in terms of financial decision making (Lusardi \& Mitchell, 2006). In this case in choosing investment, eperience could be taken as a learning process in financial management in efforts to get some profit in the future. Therefore, experience obtained by someone becomes a good teacher for both financial management and decision making of investment. Besides, experience is also essential in efforts not to make any mistakes in decision making. In general, all investors want some kinds of satisfaction from their fund/money that they have been invested with the return level in accordance with their expectation. Moreover, financial satisfaction is one of the important things/parameters for somebody's satisfaction. In short, money could be considered as the main decisive factor dealing with someone's satisfaction (Jian, Chen, \& Chen, 2014; Joo \& Grable, 2004).
This research was aimed at examining gender as a moderating variable, from which the the gender's role was an important variable dealing with the decision making of investment. Only several number of researches known how men and women had a different perception dealing with their financial situation and how to manage their finance/money. Therefore, this research was aimed at getting to know how the gender had a different behavior dealing with finance/money seen from his/her experience side, knowledge, and satisfaction in accordance with many aspects of their finance.

Gender could be defined as the difference between a woman and a man who have a different role in line with their cultural establishment. The difference would provide his/her own role, responsibility, function \& status where every culture will have a different role because gender is not a natural or biological thing but it depends much on a culture where she/he lives in. Therefore, in every decision making, the gender's role becomes an importan factor. Furthermore, the former literature showed that most women experienced what we called compulsive buyers (Faber \& O'Guinn, 1992). In this industrial era, there is an assumption that a woman has the second role after a man. In this assumption, it was said a man had a more dominant role dealing with all aspects. Indonesia as one of the developing countries, often faces a gender iniquity. In fact, a woman has also an important role in the advancement of indutry and trade.Therefore, it is essential to conduct a research on the gender role dealing with the decision making in efforts to increase their prosperity or well-being

According to the theory of conventional finance, an investor was considered that $\mathrm{s} / \mathrm{he}$ had rational thought in efforts to increase his/her prosperity but in 
fact sometimes emotion and psychology might influence his/her decision causing his/her unpredictable behavior or rational things. The theory of behavioral finance said that an investor's behavior was not as rational as they were thinking about in accordance with the concept of efficient market (Pompian, 2006). As a human being feature in general, they often did reflecting systematic and psychological things (Ritter, 2003). Furthermore, Behavioral finance learned how the people's bahavior behaved in an actual act in efforts to manage their finance. Besides, someone's emotion and cognitive reflect are the two other factors which might cause the effect to the decision making on finance, corporation, and money market.

Financial knowledge is a knowledge on the basic concept of finance. This knowledge also becomes the basic need for everyone to avoid a problem of finance. Besides, it could also support someone to make a financial plan and minimize the error level in decision making (Lusardi \& Mitchell, 2006). This means that the more knowledge about finance someone has it could motivate and encourage him to do investing. Furthermore, financial knowledge could be measured from the width of coverage of each sector in accordance with personal finance: (1) Basic Concept (TVM, planning, economy); (2) Concept of Loan (credit card, loan, hypothetic); (3) Saving concept/investment (stock, obligation, mutual fund, retired savings); (4) Concept of protection (insurance, planning of commercial agricultural enterprise and tax, identity security) (Huston, 2010).

$H_{l}$ : Financial knowledge affected the decision making of investment.

Moreover, experience in financial management is much required by anybody in decision making dealing with finance or money in doing an investment. However, the individual experience is different between and another. The experience in obtaining either profit or loss is a kind of learning process so that someone's experience will determine his/her decision in the following investment. Therefore, an investor must be more careful and think of the risk and its return before she/he does invest. Besides, financial experience about investment such as buying stocks, mutual funds, property, gold, etc. is much required by every investor. An experience like this might be experienced by himself and it also could be learned from his friends, colleague, relatives, and other people who have previously made their investments. This experience finally could be used to make both better financial management and better planning and better decision making (Chen, Kim, Nofsinger, \& Rui, 2007). An investor having an account as a broker (stock brokerage) with a longer period time, she/he might tend not to make any mistakes. Those investors have already accumulated their own experiences dealing with investment. Therefore, they might have learned to be more rational. Meanwhile, the investor who has failed to learn and tended to get lost his money from time to time with no profit, later on, he would leave the market.

$\mathrm{H}_{2}$ : Financial experience would affect the decision making of the investment.

Furthermore, the decision to do investing is much relied on someone's wish to get a greater or higher return in the future. The appropreate return would make the investor satisfied. Williams (in Joo \& Grable, 2004) proposed the following concepts: Satisfaction and financial welfare is covering several related factors related to material and non-material aspects from the situation of someone's finance including objectively about the situation of material finance and subjectively about non-material things. Someone having got a welfare of his financial condition both material and non material would feel happy and pleased so that the decision that $\mathrm{s} / \mathrm{he}$ will take in the future will be well guided. However, the research conducted by Grable and Roszkowski (2007), it was said that the relationship between money and happiness was not true (showing a weak correlation) even it was considered as a double correlation, meaning that someone's income and wealth were not the two things correlated to the measurement of someone's happiness in his life. It was also said that financial welfare was covering the psychological welfare as a whole (Norvilitis \& MacLean, 2010). In general, financial welfare has already been measured from its satisfaction level of someone as a whole in accordance with his own financial situation. However, although it was rarely to learn from the literature, in general financial satisfaction was defined as a satisfaction felt from someone's income, capable of handling an emergency condition of finance in efforts to satisfy his/her basic needs, debt level, the amount of savings, and money required for any other kinds of needs and wants for his life's purpose or target in the future (Hira \& Mugenda, 2000). However, many researchers said that financial satisfaction had an important role in affecting both directly and indirectly to many kinds of factors such as stress of marriage, solvency of finance, income, financial knowledge, education, and the stress level of finance (Joo \& Grable, 2004). Meanwhile, Jian et al. (2014) in thier research used the data from the survey on financial capability conducted in the United States of America in 2009. The result showed that there was a positive relationship between the perception of financial capability and financial satisfaction. This finding showed that the financial behavior required might cause the 
decrease of financial satisfaction. Furthermore, it was also found that the subjective financial knowledge could provide some positive contribution to the financial satisfaction. Meanwhile, positive relationship between an objective financial literacy and financial satisfaction could be found in the bivariate analysis but it was not found in multivariate analysis. The result implied that in efforts to increase the consumer's financial welfare, some educational program on consumer's finance must emphasize to the act taken and encourage the consumers (customers) to avoid the risky financial behavior involving in the financial behavior required and also increasing his financial independence (Archuleta, Dale, \& Spann, 2013). Furthermore, according to Hira and Mugenda (2000) financial satisfaction was required to measure financial satisfaction in many things covering: (a) money to be saved; (b) the amount of money owed; (c) the current condition of money/finance; (d) the capability of satisfying the long-term purpose; (e) the readiness to satisfy some emergency situation/condition; (f) some skill in financial management.

$H_{3}$ : Financial Satisfaction affected to the decision making of investment.

Gender is a nature attached in both male (man) and female (woman) which was socially and culturally constructed. Deaux and Farris (in Barber \& Odean, 2001) said that overall, a man was claimed having more capability than a woman. However, this difference arises in accordance with the masculine work which are mostly done by men. Besides, men tend to feel that they are more competent than women dealing with financial affair. Therefore, in general, men are said that they have their self confidence higher than women in line with their competence (capability) to make financial decision. However, dealing with the decision making in investment, both men and women have the same perception, that is some considerations dealing with decision making in investment. This can be established due to his/her own experience, information, trust, and some other things that might affect to his or her own perception. Furthermore, several other researches dealing with the gender effect have ever been conducted but the results were diffirent between one and another (Lestari, 2013). Gender was in fact not a memoderation in decision making of investment. Meanwhile, the research conducted by Falahati and Paim (2012) suggested that gender as a moderation could affect significantly on the consumer's experience during their childhood, agent of primary and secondary socialization, financial knowledge, and financial skill in their saving's behavior. Therefore, in line with a gender problem, in efforts to have information enrichment and to build a gender theory, a research was required to do in order to be capable of evaluating a gender effect in accordance with financial knowledge, financial experience and financial satisfaction on the decision making of investment.

$H_{4 . a}$ : Financial knowledge affected to the decision making of investment with gender as a moderating variable.

$H_{4 . b}$ : Financial experience affected to the decision making of investment with gender as a moderating variable.

$H_{4 . c}$ : Financial satisfaction affected to the decision making of investment with gender as a moderating variable.

Meanwhile, the further framework of reference could be seen from the Figure1.

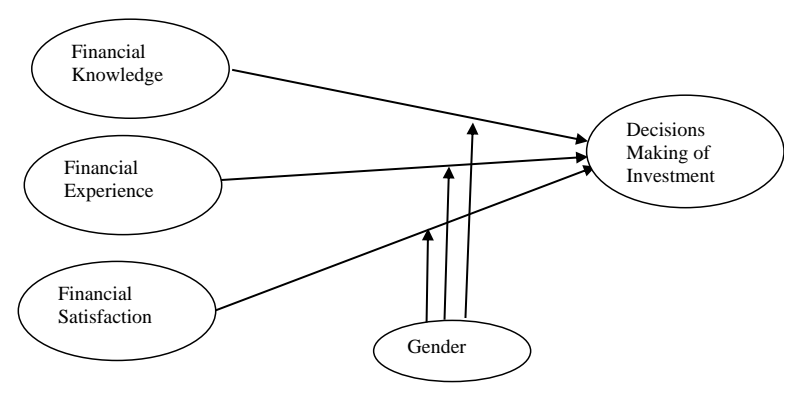

Figure 1. Research framework

\section{Research Method}

The population of this research was investors who had worked and lived in Surabaya. According to Ferdinand (2014) the sample of a research required was as many as 5-10 multiplied with its indicators. Because the number of indicators for this study is 19 , the sample that can be used is between 95 and 190.150 questionnaires have been distributed which returned and can be used as many as 102 respondents. So the sample of this research required was as many as 102 respondents.

The definition of operational variable: (a) The decision making of investment was defined as the investor's decision in choosing investment. The variable of decision making of investor was measured using an indicator: Using 5\% taken from the monthly income for conducting a business with a speculation; starting a new business without permanent income; buying some assets such as machines/machinary/ vehicle/property for conducting a business without any consideration, willing to lose money as long as his investment obtained was showing higher income compared with the inflation in the future. However, if 
the capital investment was without any security; taking an investment in accordance with intuition/instinck/ capital of feeling (Lestari, 2013). (b) Fnancial knowledge: It is a knowledge to understand some basic concepts of finance. The variable of financial knowledge could be measured from indicators, such as: I could finance some purchase through credit and I knew a question key to ask when I took a car's insurance; I also knew some investment (stock, mutual fund, property, deposit, etc.); I knew the difference between 'need and want' (Danes \& Haberman, 2007). (c) Financial experience might happen about something related to finance which had ever been faced (be undergone, being felt, be endured) either had been long or had just happened and experienced. The variable of financial experience could be measured by using Likert scale. Several variable indicators in this research like financial experience was based on the research conducted by Yulianti and Silvy (2013). It had already been planned about expense and income. The financial statement had also been made and analyzed. A statement of expense and income had also been made. (d) Financial satisfaction was a satisfaction from one financial situation nowadays and it would become the family's purpose continuously. The indicator used referred to Yulianti and Silvy (2013). By using the short-term indicator of competence then the competence of educational need, the investment's benefits of assets and the investment's benefits of emergency funds. (e) Gender means classification of feminine and masculine having an investment with the following category: men $=1$, women $=0$.

Independent variable was measured by using Likert Scale with 5 choices of answers. The answers provided were as follows: strongly disagree (score: 1); disagree (score: 2); quite agree (score: 3); agree (score: 4); strongly agree (score: 5). Furthermore, the research testing (examination) employed was analysis cross section by using Structural Equation Modeling (SEM) based on the component or variance which was called Partial Least Square (PLS) building a comprehensive track.

\section{Results and Discussion}

With a total 102 respondents in Surabaya, the majority of the respondents were male $(66.7 \%)$ and the remaining were male female (33.3\%). The majority of the respondents were between $22-41$ years old. $60 \%$ of most respondents' education is at undergraduate level. Most Respondents are married (81.4\%) and respondet's experience between 5-10 years. The type of investment taken is real assets. Respondents' profile can be reported in Table.1.
Table 1

Respondents' Profile

\begin{tabular}{|c|c|c|c|}
\hline Variable & & Frequency & Percentage \\
\hline \multirow[t]{2}{*}{ Gender } & Male & 68 & 66.7 \\
\hline & Female & 34 & 33.3 \\
\hline \multirow[t]{5}{*}{ Age } & $22-30$ & 31 & 30.4 \\
\hline & $31-41$ & 31 & 30.4 \\
\hline & $42-52$ & 17 & 16.7 \\
\hline & $53-63$ & 21 & 20.6 \\
\hline & $>64$ & 2 & 2.0 \\
\hline \multirow[t]{4}{*}{ Education } & $<$ high school & 34 & 33.3 \\
\hline & Diploma & 3 & 3.0 \\
\hline & Undergraduate & 60 & 59.8 \\
\hline & Postgraduate & 19 & 18.6 \\
\hline \multirow[t]{2}{*}{ Status } & Single & 5 & 4.9 \\
\hline & Married & 83 & 81.4 \\
\hline \multirow[t]{3}{*}{ Experience } & $<5$ & 42 & 41.1 \\
\hline & $5-10$ & 44 & 43.1 \\
\hline & $>10$ & 16 & 15.8 \\
\hline \multirow{3}{*}{$\begin{array}{l}\text { Type of invest- } \\
\text { ment }\end{array}$} & Real Asset & 44 & 43.1 \\
\hline & Financial Asset & 31 & 30.4 \\
\hline & & 27 & 26.5 \\
\hline
\end{tabular}

\section{Outliers Testing}

In efforts to detect multivariate outliers using Mahalanobis Distance test showing how far the data from a certain point center was. There were nine respondents to be analyzed and the total number was 93 respondents.

\section{The Measurement Model or Outer Model}

The value or point of loading factor in Table 2 from all variables was above 0.50 so that this had already fullfilled its validity.

Table 2

Outer Loading

\begin{tabular}{lcccc}
\hline & $\begin{array}{c}\text { Financial } \\
\text { Satisfaction }\end{array}$ & $\begin{array}{c}\text { Financial } \\
\text { Experience }\end{array}$ & $\begin{array}{c}\text { Fianancial } \\
\text { Knowlegde }\end{array}$ & $\begin{array}{c}\text { Decision } \\
\text { Making }\end{array}$ \\
\hline$X 1.1$ & & & 0.889 & \\
$X 1.2$ & & & 0.891 & \\
$X 1.3$ & & & 0.835 & \\
$X 1.4$ & & & 0.779 & \\
$X 1.5$ & & & 0.762 & \\
$X 2.1$ & & 0.977 & & \\
$X 2.2$ & & 0.973 & & \\
$X 2.3$ & & 0.944 & & \\
$X 3.1$ & 0.929 & & & \\
$X 3.2$ & 0.891 & & & \\
$X 3.3$ & 0.905 & & & \\
$X 3.4$ & 0.841 & & & \\
$X 3.5$ & 0.886 & & & 0.911 \\
$Y 1.1$ & & & & 0.904 \\
$Y 1.2$ & & & & 0.751 \\
$Y 1.3$ & & & & 0.904 \\
$Y 1.4$ & & & & 0.903 \\
$Y 1.5$ & & & & 0.939 \\
$Y 1.6$ & & & &
\end{tabular}




\section{Discriminant Validity and Composite Reliability}

In efforts to measure the reliability of data we had to measure its discriminant validity and composite reliability. Discriminat Validity could be seen from cross loading. The correlation value of indicator to its construct had to be higher compared with the correlation value between indicator and another. Meanwhile, the value of discriminant validity could be seen on Table 3. By using some criteria of FornnelLacker (Hair, Sarstedt, Ringle, \& Mena, 2012) from the result of PLS was found that the AVE of each construct was higher than the correlation value of other construct. This meant that all constructs in one model that had been estimated to fulfill the criteria of discriminant validity.

Table 3

Discriminat Validity

\begin{tabular}{lcccc}
\hline & $\begin{array}{c}\text { Financial } \\
\text { Satisfaction }\end{array}$ & $\begin{array}{c}\text { Financial } \\
\text { Experience }\end{array}$ & $\begin{array}{c}\text { Financial } \\
\text { Knowledge }\end{array}$ & $\begin{array}{c}\text { Decision } \\
\text { Making }\end{array}$ \\
\hline $\begin{array}{l}\text { Financial } \\
\text { Satisfaction }\end{array}$ & 0.891 & & & \\
$\begin{array}{l}\text { Financial } \\
\text { Experience }\end{array}$ & 0.035 & 0.965 & & \\
$\begin{array}{l}\text { Financial } \\
\text { Knowledge }\end{array}$ & 0.598 & -0.095 & 0.833 & \\
Decision Making & -0.554 & 0.260 & -0.787 & 0.887 \\
\hline
\end{tabular}

Moreover, the construct reliability could also be measured by using cronbach alpha from indikator's block measuring construct. The value of cronbach alpha showed that the value of construct was above 0.70 this meant that construct had a better reliability.

\section{Structural Model Testing (Inner Model)}

Providing the value of inner model was meant to evaluate the relationship between laten variables to be hypothesized in this research. The structural model testing with reflective construct was evaluated by using the value of $R^{2}$ for dependent variable and the value of coefficient path for independent variable and then it was evaluated for the level of its significance in accordance with the $P$-value. The value of $R^{2}$ is 0.670 indicated that the model "Strong", the value of $R^{2}$ was used to asses/evaluate the contribution of financial knowledge financial experience, financial satisfaction to the investment decision or in another words that dependent variable was affected by independent variable as many as $67 \%$ and the rest of $33 \%$ was explained by the other variable.

Based on Table 4 on Path Coefficients, the effect between variables could be analyzed as follows: the effect of financial knowledge on the decision making of investment was significant negative, with its coefficient value: -0.674 and $P$-Value $=0.00$ at $\alpha=5 \%$. This meant that in line with the decision making, the more financial knowledge someone had the more considerations he would have. When an investor knew more about all of the risks he would have dealing with investment, his decision would be based on the accurate and careful calculations. Therefore, in investment they did not want to be just speculative and relied on his intuition or feeling because they needed a permanent income. The result of this research was like and corresponded with the research conducted by Lusardi and Mitchell (2006) financial knowledge might push and encourage someone to make his financial planning more carefully and tried hard to minimize the error rate in decision making. In shorts, the more and better financial knowledge someone had it would make him be encouraged and motivated to do investing. Financial knowledge does not only affect investment, in research by Tanoto and Evelyn (2019) financial knowledge also influences the expenditureof goods.

Table 4

Path Coefficient

\begin{tabular}{cccccc}
\hline & $\begin{array}{c}\text { Original } \\
\text { Sample } \\
(\mathrm{O})\end{array}$ & $\begin{array}{c}\text { Saple } \\
\text { Mean } \\
(\mathrm{M})\end{array}$ & $\begin{array}{c}\text { Standard } \\
\text { Deviation } \\
(\mathrm{STDEV})\end{array}$ & $\begin{array}{c}T \text {-Statistics } \\
(|\mathrm{O} / \mathrm{STDEV}|)\end{array}$ & $P$-Value \\
\hline $\begin{array}{c}\text { Financial Satisfaction }> \\
\text { Investment Decision }\end{array}$ & -0.160 & -0.156 & 0.089 & 1.799 & $0.073^{*}$ \\
$\begin{array}{c}\text { Financial Experience }> \\
\text { Investment Decision }\end{array}$ & 0.208 & 0.208 & 0.065 & 3.176 & $0.002^{* *}$ \\
$\begin{array}{c}\text { Financial Knowledge }> \\
\text { Investment Decision }\end{array}$ & -0.674 & -0.685 & 0.080 & 8.394 & $0.000^{* *}$ \\
$\begin{array}{c}\text { Knowledge*Gender> } \\
\text { Investment Decision }\end{array}$ & -0.024 & -0.014 & 0.082 & 0.300 & 0.764 \\
$\begin{array}{c}\text { Experience*Gender> } \\
\text { Investment Decision }\end{array}$ & -0.003 & 0.004 & 0.068 & 0.041 & 0.967 \\
$\begin{array}{c}\text { Satisfaction*Gender }> \\
\text { Investment Decision }\end{array}$ & -0.019 & -0.017 & 0.078 & 0.240 & 0.810 \\
\hline$*$ significant at 0.1 & & & & & \\
$* *$ significant at 0.05 & & & & & \\
\hline
\end{tabular}

Based on the Table 4, it could be seen that there was a positive or significant effect of financial experience on the fianancial decision with its coefficient value 0.208 and $P$-Value was 0.00 at $\alpha=5 \%$. This positive effect meant that the investor's experience in investing s/he made some budget, report/statement and analyzed the financial statement so that when they felt that they had got enough experiences when they did investing they just relied on their own feeling and intuition. Based on the theory of behavioural finance, when someone had made some fault or mistakes due to the past fault and it would make them feel regretful. This could affect them influence their decision in the future. This condition was called as experienced regret. Therefore, in deciding to do investing, investors 
sometimes did something irrational. But when they got a big loss, they could also behave to do something causing a high/big risk. Dealing with cognitive condition when someone believed that s/he could respond and influence some event or incident (Ajzen, 2011).

The effect of financial satisfaction on the decision making of investment was quite significant. The coefficient value was -0.160 with its level of significance of $P$-Value was 0.073 at $\alpha=10 \%$. This meant that the financial satisfaction became the decesive factor for the investor's decision making. Therefore, if investors were satisfied in investing, they would take a wise decision and would consider all steps dealing with decision making. This research supported the one conducted by Hira and Mugenda (2000)

\section{Moderating Test}

To evaluate or to do testing whether gender becomes the moderating variable between financial knowledge, financial experience and financial satisfaction on the decision making in investment so that the following testings were required: The structural model test using moderating.

Financial knowledge affected to the decision making in investment using gender as a moderating variable was not significat due to its coefficient value was only -0.019 and $P$-Value was 0.810 . This meant that gender either men or women did not have a different perception in terms of their decision making if it was connected with their background knowledge. The educational condition today has already been evenly distributed because women have already got the same opportunity as men have. Meanwhile, the total number of men and women to be the respondents in this research were mostly graduated from higher education (bachelor degree).

Financial experience affected to the decision making of investment with gender as a moderating variable. The research result was not significat because it was found that the $\mathrm{p}$ Value was only 0.957 higher than $\alpha=0.1$ so that its hypothesis was rejected. However, seen from the experience effect of investor on the decision making was not significanly affected by gender. This meant that there was no difference between men and women who had got their experiences in decision making of investment. Therefore, this research did not support the research conducted by Barber and Odean (2001). According to this research, it was stated that in decision making of investment, there were some certain conciderations to think before deciding to do investing because men and women had different perceptions. This could happen due to their own experiences, information, trust and some other things which could affect their perceptions.

Financial satisfaction affected to the decision making of investment with gender as a moderating variable. It was found that the research result showed that the $P$-value was 0.810 . This meant that its hypothesis was rejected because in fact gender did not strengthen the effect of financial satisfaction to the decision making of investment. Therefore, this research did not support the previous research showing that men and women had a significant difference in accordance their financial satisfaction related to several financial aspects, such as: satisfying long-term needs, handling in an emergency situation, and their savings rate (Hira \& Mugenda, 2000; Parmitasari, 2017). Furthermore, the investment in the money market, men did trading more than women (Barber \& Odean, 2001). In decision making dealing with finance or money, it was said that women would rather avoid taking a risk than men. Besides, the implementation in decision making strategy was also different so that it could strengthen the stereotypical confidence that a woman was less capable of financial manager (Powell \& Ansic, 1997). However this research was different from those of the previous ones because the women working in Surabaya showed that the level of satisfaction was not far different from men dealing with their decision making of investment. Therefore, more and more women would rather continue their studies in higher education or Universities in efforts to find jobs as soon as they could finish their studies. Then, they could obtain their own income or salary and later they could be self development, self actualization and finally having higher independent women in line with financial affairs. According to the data from the World Bank, in the year 2018 there were getting more women working reaching up to $50.7 \%$ of Indonesian women from the ages of 15 years old up who were participating in the work force (both as permanent employees and being job seekers).

\section{Conclusion and Implication}

\section{Conclusion}

This research examined or investigated the effect of financial experience, financial knowledge and financial satisfaction to the decision making of investment. Based on the research which had been already conducted and the discussion above, it could be concluded as follows: 
Financial experience affected to the decision making of investment. This result showed that an inverstor having more experiences in investment, he would tend to do the decision making in accordance with his intuition because they thought that based on their experiences which had been done, the investment could run very well. Then, financial knowledge affected significantly to the decision making of investment. This research showed that an investor having higher or more knowledge to the financial risk, the decision making of investment would rather consider more careful calculations in investment. Meanwhile, financial satisfaction also affected significantly to the decision making of investment. This could be explained that dealing with investment, investors feeling satisfied would take their decision wisely. Therefore, they would consider thier steps very carefully before decision making was taken. As a moderating variable in this research, gender did not affect significantly to the decision making of investment. This meant that neither men nor women were different in line with their financial experience, financial knowledge and financial satisfaction to the decision making of investment.

It is suggested to the next researchers or further research that the sample of research were necessarily to be added. Furthermore, gender as a variable in this research had not been made as a moderating variable. Therefore, it needed to be examined using another variable to be a moderating variable, such as someone's age and marital status. Age can be a strong driver in investing, the more a person approaches old age/retirement, the intention to invest is stronger. Marital status can make a person to increase investment interest, due to the growing need for life with his wife/and children.

\section{Implications}

The result of this research showed that in doing an investment, the Surabaya society in fact there was no difference between men and women if it was seen from their knowledge, experience and satisfaction dealing with investment. This showed that women investors could achieve their independence financially in doing the investment, earning a living the same as the men have. Due to the women had the same potency as the men did finally their opportunities for business and investment were widely open.

\section{References}

Ajzen, I. (2011). The theory of planned behaviour: Reactions and reflections. Psychology \& Health, 26(9), 1113-1127. https://doi.org/10.1080/0887 0446.2011 .613995
Archuleta, K. L., Dale, A., \& Spann, S. M. (2013). College students and financial distress: Exploring debt, financial satisfaction, and financial anxiety. Journal of Financial Counseling and Planning, 24(2), 50-62.

Barber, B. M., \& Odean, T. (2001). Boys will be boys: Gender, overconfidence, and common stock investment. Quarterly Journal of Economics, 116(1), 261-292. https://doi.org/10.1162/0033 55301556400

Chen, G., Kim, K. A., Nofsinger, J. R., \& Rui, O. M. (2007). Trading performance, disposition effect, overconfidence, representativeness bias, and experience of emerging market investors. Journal of Behavioral Decision Making, 20(4), 425-451. https://doi.org/10.1002/bd m.561

Danes, S. M., \& Haberman, H. R. (2007). Teen financial knowledge, self-efficacy, and behavior: A gendered view. Journal of Financial Counseling and Planning, 18(2), 48-60.

Faber, R. J., \& O'Guinn, T. C. (1992). A clinical screener for compulsive buying. Journal of Consumer Research, 19(3), 459. https://doi.org/ 10.1086/209315

Falahati, L., \& Paim, L. (2012). Gender differences in saving behavior determinants among university students. Journal of Basic and Applied Scientific Research, 2(6), 5848-5854.

Ferdinand, A. (2014). Metode penelitian manajemen. Semarang: BP Universitas Diponegoro.

Grable, J. E., \& Roszkowski, M. J. (2007). Selfassessments of risk tolerance by women and men. Psychological Reports, 100(3), 795-802. https://doi.org/10.2466/PR0.100.3.795-802

Hair, J. F., Sarstedt, M., Ringle, C. M., \& Mena, J. A. (2012). An assessment of the use of partial least squares structural equation modeling in marketing research. Journal of the Academy of Marketing Science, 40(3), 414-433. https://doi. org/10.1007/s11747-011-0261-6

Hira, T. K., \& Mugenda, O. (2000). Gender differences in financial perceptions, behaviors and satisfaction. Retrieved from https://www.researchgate.net/publication/242079683_Gender_Differences_in_Financial_Perceptions_Behaviors_an d_Satisfaction

Huston, S. J. (2010). Measuring financial literacy. The Journal of Consumer Affairs, 44(2), 296-316. https://doi.org/10.1111/j.1745-6606.2010.01170.x

Jian, J., Chen, C., \& Chen, F. (2014a). Consumer financial capability and financial satisfaction. Social Indicators Research, 118(1), 415-432. https://doi.org/10.1007/s11205-013-0414-8 
Joo, S. H., \& Grable, J. E. (2004). An exploratory framework of the determinants of financial satisfaction. Journal of Family and Economic Issues, 25(1), 25-50. https://doi.org/10.102 3/B:JEEI.0000016722.37994.9f

Lestari, W. (2013). Religiusitas dan persepsi risiko dalam pengambilan keputusan investasi pada perspektif gender. Journal of Business and Banking, 3(2), 189-200. https://doi.org/10.14 414/jbb.v3i2.236

Lusardi, A., \& Mitchell, O. S. (2006). Financial literacy: Implication for retirement wellbeing. Wharton School, University of Pennsylvania, Pension Research Council Working Paper n. 1. Retrieved from http://www.nber.org/papers/ w17078

Norvilitis, J. M., \& MacLean, M. G. (2010). The role of parents in college students' financial behaviors and attitudes. Journal of Economic Psychology, 31(1), 55-63. https://doi.org/10. 1016/j.joep.2009.10.003

Parmitasari, R. D. A. (2017). Gender dan kepuasan keuangan investor pasar modal di Sulawesi Selatan. Patria Artha Management Journal, 1(2), 247-266.
Pertiwi, T. K., Yuniningsih, Y., \& Anwar, M. (2019). The biased factors of investor's behavior in stock exchange trading. Management Science Letters, 9(6), 835-842. https://doi.org/10.5267/j.msl. 2019.3.005

Pompian, M. M. (2006). Behavioral finance and wealth management. New Jersey, NJ: John Wiley \& Sons Inc.

Powell, M., \& Ansic, D. (1997). Gender differences in risk behaviour in financial decision-making. Journal of Economic Psychology, 18(6), 605628. https://doi.org/10.1016/S0167-4870(97) 00026-3

Ritter, J. R. (2003). Behavioral finance. Pacific Basin Finance Journal, 11(4), 429-437. https://doi. org/10.1016/S0927-538X(03)00048-9

Tanoto, S., \& Evelyn, E. (2019). Financial knowledge, financial wellbeing, and online shopping addiction among young Indonesians. Jurnal Manajemen dan Kewirausahaan, 21(1), 32-40. https://doi.org/10.9744/jmk.21.1.32-40

Yulianti, N., \& Silvy, M. (2013). Sikap pengelola keuangan dan perilaku perencanaan investasi keluarga di Surabaya. Journal of Business and Banking, 3(1), 57-68. 